\title{
A STUDY OF STAKEHOLDER PERSPECTIVES OF ENTERPRISE ARCHITECTURE METHODOLOGY (TOGAF FRAMEWORK)
}

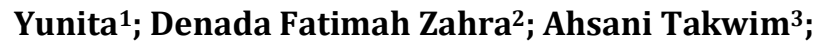 \\ Magister of Information System \\ STMIK LIKMI, Bandung, Indonesia \\ www.stmiklikmi.ac.id \\ yunita.nambela@gmail.com ${ }^{1 *}$, denada.zahra@gmail.com², \\ ahsanitakwim10@gmail.com ${ }^{3}$ \\ (*) Corresponding Author
}

\begin{abstract}
Abstrak
Arsitektur enterprise adalah metode atau penjelasan tentang bagaimana merencanakan, menyusun, merancang, dan merealisasikan sistem struktur perusahaan, proses bisnis, sistem informasi, dan infrastruktur terkait serta penjelasan tentang bagaimana merancang sistem yang dapat mendukung kebutuhan bisnis dan teknologi terkait untuk mewujudkannya visi dan misi mencapai hasil yang ditargetkan. Framework yang digunakan dalam penelitian ini adalah TOGAF dan FEAF. TOGAF memiliki kerangka kerja yang detail dan menyeluruh, dan memiliki metodologi yang mendukung penerapannya tetapi tidak disesuaikan dari sudut pandang stakeholder. Tujuan penelitian ini untuk mengembangkan dua buah framework dengan membandingkan perbedaan yang dimiliki masing-masing Framework dalam sudut pandang stakeholder. Metodologi penelitian diawali dengan studi literatur dan dilanjutkan dengan analisis perbandingan Framework TOGAF dan FEAF. Hasil penelitian menunjukan bahwa. Hasil akhir penelitian ini adalah pengembangan kerangka kerja TOGAF dengan komponen yang dimiliki FEAF dalam sudut pandang stakeholder sehingga menghasilkan kerangka kerja TOGAF yang sesuai dengan kebutuhan khusus organisasi.
\end{abstract}

Kata kunci: Metodologi, EA, TOGAF, FEAF, stakeholder

\begin{abstract}
Enterprise architecture is a method or explanation of how to plan, compile, structure, and realize company structures, business processes, information systems, and related infrastructure as well as an explanation of how to design systems that can support business needs and related technology to make vision and mission achieve results. targeted. The framework used in this research is TOGAF and FEAF. TOGAF has a detailed and comprehensive framework and has a methodology that supports its application but is invincible from a stakeholder point of view. The aim of this study is to develop two frameworks by comparing the differences that each Framework has from the perspective of stakeholders. The research methodology begins with a literature study and analysis with a comparison of the TOGAF and FEAF Frameworks. The results showed that. The final result of this research is the TOGAF framework with the components that are owned by FEAF from the perspective of the stakeholders so as to produce a TOGAF framework that suits the specific needs of the organization.
\end{abstract}

Keywords: Methodology, EA, TOGAF, FEAF, stakeholder

\section{INTRODUCTION}

Enterprise Architecture is a method or explanation of how to plan, compile, design, and realize an enterprise structure system, business processes, information systems and related infrastructure and an explanation of how to design a system that can support business needs and related technology to realize the vision. and the mission of achieving the targeted results. Enterprise information architecture will become a reference in the term technology investment short and long term by considering the interests of a whole (Kustiyahningsih, 2013).

The methodology is a collection of methods that serve to describe how a collection of activities can be carried out. In general, the methodology includes certain techniques and procedures. 
During the last decade, the methodology in planning Enterprise Architecture is still lacking, most of the model approaches that are made only cover information (data) or business processes, but do not cover other aspects such as technology and application architecture.

In determining the scope of limitations and determining the content or content of an Enterprise Architecture, it can use a certain framework. The framework itself is a logical structure for classifying and organizing a set of methods, concepts, and technology as well as changes in a design. Several very popular frameworks are often used by many corporate or institutional organizations, including The Open Group Architecture Framework (TOGAF), Zachman Framework, Federal Enterprise Architecture Framework (FEAF)(Urbaczewski \& Mrdalj, 2006).

Function in determining usage framework or election framework to develop the Enterprise Architecture several different criteria are important to pay attention to and can of course be used as a reference, for example, the purpose of Enterprise Architecture by looking at the definition and understanding of architecture, determining easy-to-follow architectural processes and support for architectural change. Also besides, the input or input to EA activities also needs to be considered, such as technology input and business drivers, and finally, the output or output of the EA activity includes transitional design for evolution, business models, and changes (Perez-Castillo et al., 2019). Apart from that, the framework criteria are also a very important part that must be had for designing Enterprise Architecture (Setiawan, 2009).

TOGAF conquers the complete criteria of the criteria and its compilation components (Murti et al., 2017). However, like other frameworks, TOGAF has drawbacks. TOGAF does not consider stakeholder viewpoints such as the FEAF Framework. So that the purpose of this study is to develop two frameworks by comparing the differences that each Framework has from the perspective of stakeholders. This research was conducted using a method that begins with a literature study and continues with a comparative analysis of the TOGAF and FEAF Frameworks.

Previous research conducted by (Pramudita \& Safitri, 2016) showed that the preliminary phase, arcitectures vision, business architecture, IS architecture required an owner's perspective to determine needs from vision, business, data and enterprise applications. (Purnasari \& Assegaff, 2018) showed that at each stage, the TOGAF ADM can be executed right when the business processes in the organization are completely and correctly understood and identified.

(Tang et al., 2004) suggest the use of architectural risk analysis to determine how much architectural design is required in the TOGAF Framework. (Milani \& Veenpere, 2017) suggests combining all the different elements such as business processes, activating information systems, data flows and platforms, will not ensure which investment will lead to achieving goals. So it can be seen that the gap in what factors should be added to the TOGAF Framework.

From the previous description of the methodology on the Enterprise Architecture as well as the criteria for use EA Framework, then the next writer will describe Enterprise Architecture Framework which is often used and provides a new suggestion to the methodology of one Framework that is TOGAF Framework.

\section{MATERIALS AND METHODS}

\section{A. TOGAF Framework}

In developing an enterprise architecture, TOGAF is one of the most widely used frameworks. And this is because TOGAF has several features that the Zachman framework does not have, namely in addition to using the object approach, it also pays attention to other aspects such as gap analysis, governance, and change management (Hadiana, 2016).

The Open Group Architecture Framework (TOGAF) is a detailed and detailed method on how to build, manage and also how to implement EA and SI which is commonly called ADM or Architecture Development Method (The Open Group, 2018).

One of the advantages of using the TOGAF framework is that it is flexible and open source. TOGAF provides a detailed method of how to build and refine and implement an enterprise architecture and information system called the Architecture Development Method (ADM) (Harrison, 2018).

ADM is a generic method that contains a set of activities used in modeling enterprise architecture development. This method can also be used as a guide or tool for planning, designing, developing and implementing information systems architecture for organizations (Yunis \& Surendro, 2009). ADM is iterative, which is an interdependent process, meaning that each output from each phase will be the input for the next phase. Besides that, ADM is also dynamic and continuous (Tuwondila et al., 2018). 
In providing a methodology proposed in the TOGAF framework, it is necessary to compare it with other methods, so that it can be seen the shortcomings of the TOGAF methodology, which later will become reasons or material for consideration in proposing. The author will compare the TOGAF methodology with the FEAF, this is because the FEAF methodology is considered almost complete from the criteria and components of its composition when compared to the ZACHMAN method and is considered less complete than the TOGAF methodology itself which can be seen in the comparison in Table 1.

\section{B. FEAF Framework}

In (Hadiana, 2016) explained that the Federal Enterprise Architecture Framework (FEAF) is part or sub-framework of Zachman. FEAF focuses more on the four main components of an enterprise architecture. FEAF which includes 15 cells that produce different artifacts including data architecture, applications and technology, and is adapted to the five system perspectives in the Zachman framework, namely 1. Planner; 2. Owner; 3. Designer; 4. Builder; and 5. Subcontractor.

The iterative stages that are generally carried out in the development of enterprise architecture using the FEAF framework are as follows:

1. Obtain executive buy-in and support

2. Establish management structure and control

3. Define an architecture process and approach

4. Develop baseline enterprise architecture

5. Develop target enterprise architecture

6. Develop the sequencing plan

7. Use the enterprise architecture

8. Maintain the enterprise architecture

For some enterprises, none of these methodologies are completely complete a solution. There is another approach called the blended methodology, which is selecting parts of the methodology, modify, combine and structure them for the specific needs of the organization (Wartika \& Supriana, 2011).

Architecture to develop an enterprise architecture requires adoption or selfdevelopment of an EA framework. The results of a survey conducted by IFEAD (Institute for Enterprise Architecture Development) in the 2003-2005 period types of frameworks that can be utilized and often used in the development of enterprise architecture, namely Zachman, FEAF, and TOGAF Framework. New application development needs to be integrated with existing applications to form an integration to support business and provide data and information needed by each unit (Purnasari \& Assegaff, 2018).
Based on the criteria for using the EA framework described in the previous chapter, a comparison of the three frameworks was carried out which will be explained in the following Table 1. (Setiawan, 2009).

Table 1. EA Framework Comparison

\begin{tabular}{|c|c|c|c|}
\hline & Zachman & FEAF & TOGAF \\
\hline $\begin{array}{l}\text { Definition of } \\
\text { Architecture } \\
\text { and } \\
\text { Understanding }\end{array}$ & $\begin{array}{c}\text { Partia } \\
1\end{array}$ & Yes & $\begin{array}{l}\text { Yes, at the } \\
\text { preliminar } \\
\text { y phase }\end{array}$ \\
\hline $\begin{array}{l}\text { Detailed } \\
\text { Architectural } \\
\text { Processes }\end{array}$ & Yes & Not & $\begin{array}{l}\text { Yes, ADM } \\
\text { with } 9 \\
\text { Detailed } \\
\text { Phases }\end{array}$ \\
\hline $\begin{array}{l}\text { Support for } \\
\text { Architectural } \\
\text { Evolution }\end{array}$ & Not & Yes & $\begin{array}{l}\text { Yes, there } \\
\text { is a } \\
\text { Migration } \\
\text { Planning } \\
\text { Phase }\end{array}$ \\
\hline $\begin{array}{l}\text { Standardizati } \\
\text { on }\end{array}$ & Not & Not & $\begin{array}{l}\text { Yes, } \\
\text { Provide } \\
\text { TRM, } \\
\text { Standards } \\
\text { Informatio } \\
\text { n }\end{array}$ \\
\hline $\begin{array}{l}\text { Architecture } \\
\text { Knowledge } \\
\text { Base }\end{array}$ & Not & Yes & Yes \\
\hline $\begin{array}{l}\text { Business } \\
\text { Drivers }\end{array}$ & Partial & Yes & Yes \\
\hline $\begin{array}{l}\text { Technology } \\
\text { Input }\end{array}$ & Not & Yes & Yes \\
\hline $\begin{array}{l}\text { Business } \\
\text { Model }\end{array}$ & Yes & Yes & Yes \\
\hline $\begin{array}{l}\text { Transitional } \\
\text { Design }\end{array}$ & Not & Yes & $\begin{array}{l}\text { Yes, } \\
\text { Results of } \\
\text { the } \\
\text { Migration } \\
\text { Planning } \\
\text { Phase }\end{array}$ \\
\hline Neutrality & Yes & Not & Yes \\
\hline $\begin{array}{l}\text { Provides } \\
\text { Architectural } \\
\text { Principles }\end{array}$ & Not & $\begin{array}{l}\text { No, just for } \\
\text { the FEAF } \\
\text { characteristi } \\
\text { cs }\end{array}$ & Yes \\
\hline
\end{tabular}

Source: (Setiawan, 2009)

Based on the explanation of the types of the framework in table 1 . it can be concluded that TOGAF was chosen as a reference in developing the proposed methodology for Enterprise Architecture because it is considered complete from the criteria and components of its preparation. 
Through a description of the results of the comparison of the two methodologies, namely TOGAF and FEAF, it can be seen that the difference is in their characteristics, namely the stakeholder point of view. In the FEAF methodology, it is adjusted to the perspectives of the relevant stakeholders, while the TOGAF is not visible.

\section{RESULT AND DISCUSSION}

Based on these differences, the authors propose to provide or add stakeholder perspectives or perspectives to the TOGAF methodology. The following table shows the proposed methodology that is added to several phases in the TOGAF methodology.

Table 2. Proposed TOGAF Methodology

\begin{tabular}{|c|c|c|}
\hline $\begin{array}{c}\text { TOGAF } \\
\text { methodology }\end{array}$ & $\begin{array}{c}\text { Proposed } \\
\text { Methodology }\end{array}$ & Reason \\
\hline $\begin{array}{l}\text { Architecture } \\
\text { Vision }\end{array}$ & $\begin{array}{l}\text { Add } \\
\text { perspectives } \\
\text { from planner } \\
\text { and owner }\end{array}$ & $\begin{array}{l}\text { At this stage, the point } \\
\text { of view of the planner } \\
\text { and owner is } \\
\text { important because } \\
\text { they are the owners } \\
\text { who certainly } \\
\text { understand the most } \\
\text { about the company's } \\
\text { vision and mission, so } \\
\text { the owner or } \\
\text { important owners } \\
\text { know the plan to make } \\
\text { Enterprise } \\
\text { architecture so that it } \\
\text { is in line with their } \\
\text { company's vision and } \\
\text { mission. }\end{array}$ \\
\hline $\begin{array}{l}\text { Business } \\
\text { Architecture }\end{array}$ & $\begin{array}{l}\text { Add } \\
\text { perspectives } \\
\text { from planner } \\
\text { and owner }\end{array}$ & $\begin{array}{l}\text { The owner has a big } \\
\text { enough share in the } \\
\text { company so that what } \\
\text { will be made is by the } \\
\text { expectations and } \\
\text { business goals that } \\
\text { were previously } \\
\text { planned. }\end{array}$ \\
\hline $\begin{array}{l}\text { Information } \\
\text { System } \\
\text { Architecture } \\
\text { and Technology } \\
\text { Architecture }\end{array}$ & $\begin{array}{l}\text { Add } \\
\text { the point of } \\
\text { view of the } \\
\text { designer, } \\
\text { builder, and } \\
\text { subcontractor }\end{array}$ & $\begin{array}{l}\text { At this stage of } \\
\text { realization, so that the } \\
\text { results obtained are by } \\
\text { what was defined at } \\
\text { the beginning, the } \\
\text { perspective of the } \\
\text { designer, builder, and } \\
\text { subcontractor is very } \\
\text { important at this stage. }\end{array}$ \\
\hline $\begin{array}{l}\text { Architecture } \\
\text { Implementation } \\
\text { Governance }\end{array}$ & $\begin{array}{l}\text { Add } \\
\text { perspectives } \\
\text { from planner } \\
\text { and owner }\end{array}$ & $\begin{array}{l}\text { The goal is to equalize } \\
\text { the perception } \\
\text { between what has } \\
\text { been planned in the } \\
\text { beginning with the } \\
\text { implementation of the } \\
\text { final result, so the } \\
\text { perspective of the } \\
\text { planner and owner is } \\
\text { needed. }\end{array}$ \\
\hline
\end{tabular}

\section{CONCLUSIONS AND SUGGESTION}

Enterprise Architecture Framework, of course, it can be different in each enterprise. In its realization, the EA framework certainly has advantages and disadvantages, but TOGAF is a framework that can be said to be complete and almost perfect because of its detailed and thoroughly detailed methodology. When compared with the FEAF methodology, the TOGAF methodology has a difference or can be said to be a drawback where the TOGAF methodology does not have a stakeholder point of view or perspective, therefore the methodology proposed by the author is to add the TOGAF methodology with the characteristics of the viewpoint possessed by the FEAF, namely stakeholder point of view. Hopefully, this suggestion can be of benefit to readers.

\section{REFERENCES}

Hadiana, A. (2016). Perencanaan \& Pengembangan Sistem Informasi Terpadu. Megatama: Bandung.

Harrison, R. (2018). Togaf(r) 9 Foundation Study Guide (4th ed.). Van Haren.

Kustiyahningsih, Y. (2013). Perencanaan Arsitektur Enterprise Menggunakan Metode Togaf Adm (Studi Kasus: Rsud Dr.Soegiri Lamongan). In Program Studi MMT-ITS (Ed.), Prosiding Seminar Nasional Manajemen Teknologi XVIII (pp. 1-8). Program Studi MMT-ITS.

https://mmt.its.ac.id/download/SEMNAS/SE MNAS XVIII/MTI/17. Prosiding Yeni-TogafOK.pdf

Milani, F. P., \& Veenpere, H. (2017). Comparing Enterprise Architecture Frameworks- A Case Study at the Estonian Rescue Board. 71. https://doi.org/10.1056/NEJMe068114

Murti, D. N., Prasetyo, Y. A., \& Fajrillah, A. A. N. (2017). Perancangan Enterprise Architecture Pada Fungsi Sumber Daya Manusia (SDM) Di Universitas Telkom Menggunakan Togaf ADM. Jurnal Rekayasa Sistem \& Industri (JRSI), 4(01), 47. https://doi.org/10.25124/jrsi.v4i01.233

Perez-Castillo, R., Ruiz, F., Piattini, M., \& Ebert, C. (2019). Enterprise Architecture. IEEE Software, 36(4), 12-19. https://doi.org/10.1109/MS.2019.2909329 
Pramudita, R., \& Safitri, N. (2016). Integrasi Zachman Framework dan TOGAF ADM ( Architecture Development Method ). Information System for Educators and Professionals, 1(2), 157-166.

Purnasari, M., \& Assegaff, S. (2018). Perancangan Arsitektur Sistem Informasi Menggunakan Togaf Adm Pada Sma Negeri 1 Muara Bungo. Jurnal Manajemen Sistem Informasi, 3(2), 1030-1041.

Setiawan, E. B. (2009). Pemilihan EA Framework. Seminar Nasional Aplikasi Teknologi Informasi (SNATI), 114-119. https://journal.uii.ac.id/Snati/article/view/ 1091

Tang, A., Han, J., \& Chen, P. (2004). A comparative analysis of architecture frameworks. Proceedings - Asia-Pacific Software Engineering Conference, APSEC, January, 640647. https://doi.org/10.1109/APSEC.2004.2

The Open Group. (2018). Welcome to the TOGAF® Standard, Version 9.2, a standard of The Open Group. Pubs.Opengroup.Org. https://pubs.opengroup.org/architecture/to gaf9-doc/arch/

Tuwondila, A. G., Sitokdana, M. N. N., \& Wijaya, A. F. (2018). PERENCANAAN STRATEGIS SI/TI PEMERINTAHAN MENGGUNAKAN THE OPEN GROUP ARCHITECTURE FRAMEWORK (TOGAF). Seminar Nasional Sistem Informasi Indonesia (SESINDO), November, 79-84. http://is.its.ac.id/pubs/oajis/index.php/hom e/detail/1827/PERENCANAAN-STRATEGISSITI-PEMERINTAHAN-MENGGUNAKANTHE-OPEN-GROUP-ARCHITECTUREFRAMEWORK-TOGAF

Urbaczewski, L., \& Mrdalj, S. (2006). a Comparison of Enterprise Architecture Frameworks. Issues in Information Systems, 7(2), 18-23. https://iacis.org/iis/2006/Urbaczewki_Mrda lj.pdf

Wartika, W., \& Supriana, I. (2011). Analisis Perbandingan Komponen Dan Karakteristik Enterprise Architecture Framework. 2011 Konferensi Nasional Sistem Dan Informatika, 407-412.

https://www.researchgate.net/publication/ 259359209_ANALISIS_PERBANDINGAN_KO MPONEN_DAN_KARAKTERISTIK_ENTERPRIS E_ARCHITECTURE_FRAMEWORK
Yunis, R., \& Surendro, K. (2009). Model Enterprise Architecture Untuk Perguruan Tinggi di Indonesia. Seminar Nasional Informatika (SEMNASIF), I(5), E72-E79. http://jurnal.upnyk.ac.id/index.php/semnasi f/article/view/909/0 
